AN EFFECT OF TWISTED TAPE WITH NANOFLUID ON THE

PERFORMANCE OF DOUBLE PIPE HEAT EXCHANGER:

\title{
A COMPREHENSIVE REVIEW
}

\section{SANJAY KUMAR SINGH \& ARVIND KUMAR}

Maulana Azad National Institute of Technology, Bhopal, Madhya Pradesh, India

\section{ABSTRACT}

The phenomenon of heat transfer is employed in numerous applications such as refrigeration, airconditioning, food processing, etc. Heat exchangers are used for efficient heat transfer and therefore, the performance of a heat exchanger is important. Cutting edge, innovative and cost-effective techniques are required to achieve efficient heat transfer. Twisted tape (TT) inserts which is a type of passive heat transfer enhancement technique are widely researched. This article delivers an assessment on diverse types of TT in double pipe heat exchangers with different nanofluids. The influence of tape inserts with nano fluids on thermal performance factor ( $\eta$ ), Nusselt Number (Nu), friction factor $(f)$ and rate of heat transfer are comprehensively discussed. Application of twisted tape inserts were demonstrated to be more useful in laminar flows w. r. t. turbulent flows. On the contrary, when solid nanoparticles were employed with a high value of $\varphi$, heat transfer rate was better in turbulent flows than in laminar flows.

KEYWORDS: Friction Factor, Heat Exchanger, Nanofluid, Thermal Performance Factor \& Twisted Tape Insert

Received: Dec 11, 2018; Accepted: Dec 31, 2018; Published: Jan 25, 2019; Paper Id.: IJMPERDFEB201951

Nomenclature

$\begin{array}{cl}\eta & \text { Performance evaluation factor } \\ \alpha & \text { Attack angle } \\ \alpha & \text { Wing inclination angle } \\ \varphi & \text { Volume fraction } \\ \text { a } & \text { Perforated width } \\ \mathrm{f} & \text { Friction factor } \\ \mathrm{h} & \text { Heat transfer coefficient } \\ \mathrm{Re} & \text { Reynolds Number } \\ \mathrm{Nu} & \text { Nusselt Number } \\ \mathrm{T}_{\mathrm{c}} & \text { Twist length } \\ \mathrm{W}_{\mathrm{T}} & \text { Width of tape } \\ \mathrm{S}_{\mathrm{T}} & \text { Axial spacing } \\ \mathrm{D} & \text { Diameter of the inner tube } \\ \mathrm{L} & \text { Length of the tube } \\ \mathrm{N} & \text { Number of twisted tapes } \\ \mathrm{d}_{\mathrm{e}} & \text { Hydraulic diameter }\end{array}$

$\begin{array}{cl}\text { DR } & \text { Depth ratio } \\ \text { WR } & \text { Width ratio } \\ \text { PR } & \text { Pitch ratio } \\ \text { PI } & \text { Performance index } \\ \text { BR } & \text { Blockage ratio } \\ \text { TT } & \text { Twisted tape } \\ \text { TR } & \text { Twist ratio } \\ \Delta \text { P } & \text { Pressure drop } \\ \text { WDR } & \text { Wing-depth ratio } \\ \text { PWR } & \text { Perforated width ratio } \\ \text { BWR } & \text { Baffle width ratio } \\ \text { BTR } & \text { Baffle twist ratio } \\ \text { RRP } & \text { Relative rib pitch } \\ \text { HDR } & \text { Hole-diameter ratio } \\ \text { PVA } & \text { Poly vinyl alcohol } \\ \text { CC- } & \text { Counter current in quadruple counter tape } \\ \text { QTS } & \text { in cross direction }\end{array}$




\section{INTRODUCTION}

The conversion, utilization and recovery of energy in every industrial, commercial and domestic application involve a heat exchange process. Double pipe heat exchanger (DPHE) is one of the most simple and widely applicable heat exchanger. Due to its simple design and low cost it is commonly used in small scale industries like food, oil, chemical, pasteurizing, reheating, preheating, effluent heating process etc.[1].

Heat loss while transfer is an usual phenomenon and therefore, heat transfer enhancement techniques are required for economical and efficient heat transfer. Heat Transfer Enhancement can be achieved by three methods (i) Active Method (ii) Passive Method and (iii) Combination of these two. In active method, some external power or energy is required for the enhancer to improve heat transfer, such as induced pulsation by cams and reciprocating plungers, mechanical aids, fluid vibration, surface vibration, application of electrostatic fields, application of magnetic field to disturb the seeded light particles in a flow stream, etc. [2]. On the other hand, passive method employs geometrical or surface alterations in the flow channel. These modifications are carried out by inducing inserts or supplementary devices. Swirl flow devices, extended surfaces, treated surfaces, rough surfaces; coiled tubes, surface tension devices, etc. are used in passive heat transfer enhancement pathway [3-6]. The combination of active and passive methods is called as compound method (e. g. rough surface with fluid vibration).

Passive method is the most popularly used method as it employs no external power and enhance the heat transfer rate to a significant extent. Therefore, an optimal heat transfer rate is obtained as economical pumping power. Tube inserts technique is commonly used as one of the routes under passive method. Few examples of tube inserts in a heat exchanger are twisted tape, helical spring, ribs, conical nozzle, conical ring, etc. [7]. Among all the commonly used tube inserts, twisted tape insert is considered as a primary choice and therefore extensively studied and researched by numerous researchers [8-23] worldwide. A typical twisted tape is shown in Figure 1.

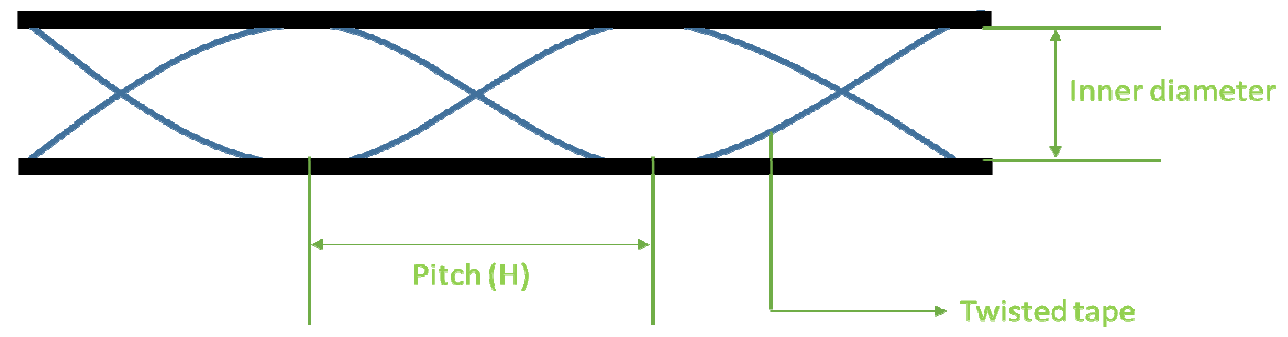

Figure 1: Structure of Typical Twisted Tape

\section{THE IMPACT OF THE COMBINATION OF TWISTED TAPE INSERTS WITH NANOFLUID}

Recently, many researchers $[8,10,12,15,18,24,25,26,27,48]$ have employed different nano fluids along with twisted tape inserts in diverse heat exchanger to enhance desirable parameters such as heat transfer rate and thermal performance efficiency. Some major studies of the influence of twisted tape inserts in the presence of nanofluid are summarized in Table 1.

Sundar and co-authors [24] and Sharma and co-authors [49] investigated h and f for transitional nanofluid flow inside a circular tube equipped with twisted tape inserts. They reported an enhancement of $23.69 \%$ and $44.71 \%$ respectively, vis-à-vis employing nanofluid and twisted tape and, twisted tape alone, in the rate of heat transfer at Reynolds Number 9000 . Furthermore, they noted an increase of 1.21 times in the value of $\mathrm{f}$ while using $0.1 \%$ nanoparticle volume 
fraction with tape inserts as compared to pure water in plain tube. Sundar et al. [50] assessed the turbulent flow and thermal fields for a combination of magnetic nanofluid and full length tape inserts, in a pipe. They demonstrated an increase of $30.96 \%$ in heat transfer rate using the nanofluid (volume fraction - $0.6 \%$ ) at Reynolds

Number 22000, with respect to plain tube. On the other hand, an enhancement of $18.49 \%$ in heat transfer rate and $1.122 \%$ in friction factor was noted employing full length twisted tape w. r. t. plain tube.

Table 1: Major Studies about Twisted Tape Inserts with Nanofluid

\begin{tabular}{|c|c|c|c|c|c|}
\hline Type of Research & $\begin{array}{c}\text { Specifications of } \\
\text { Nanofluid } \\
\text { (type } / \varphi / \text { Particle } \\
\text { diameter in } \mathrm{nm} \text { ) } \\
\end{array}$ & $\begin{array}{c}\text { Type / } \\
\text { Configuration of } \\
\text { Twisted Tape }\end{array}$ & Condition & Findings & Reference \\
\hline Experimental & 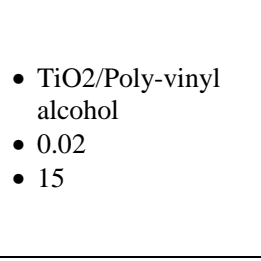 & $\begin{array}{l}\text { Full length TT } \\
\text { Reduced width TT } \\
\text { TR }=2 \text { to } 5 \\
\text { Width }=12 \text { to } 16\end{array}$ & $\begin{array}{c}800 \leq \mathrm{Re} \leq \\
30000\end{array}$ & $\begin{array}{l}\text { - Nu and } \mathrm{f} \text { for full length TT with } \\
\text { nanofluid were found to be } 90-220 \% \\
\text { and } 100-270 \% \text { higher than plain tube } \\
\text { at TR }=3 \text { and } 5 \text { respectively } \\
\text { - Highest } \eta \text { was obtained up to } 1.75 \text { by } \\
\text { using reduced width TT at TR }=2 \text {, } \\
\text { width }=16, \varphi=0.5 \% \text { and } \operatorname{Re}=800 \text { - } \\
30000\end{array}$ & [39] \\
\hline Experimental & $\begin{array}{l}\text { - } \mathrm{Al} 2 \mathrm{O} 3 / \text { ethylene } \\
\text { glycol (EG) } \\
-0.005,0.01 \text { and } \\
0.015 \\
\end{array}$ & $\begin{array}{l}\text { Conventional TT } \\
\mathrm{TR}=2,3.6 \text { and } 5\end{array}$ & $\begin{array}{c}6000 \leq \operatorname{Re} \leq \\
30000\end{array}$ & $\begin{array}{l}\text { - Using the nanofluid in corrugated tube } \\
\text { with TT at TR }=2, \varphi=0.5 \% \text {, } \\
\text { maximum } \eta \text { obtained was } 4.2\end{array}$ & [34] \\
\hline $\begin{array}{l}\text { Numerical } \\
\text { (single phase } \\
\text { approach) }\end{array}$ & $\begin{array}{l}\text { - } \mathrm{A} 12 \mathrm{O} 3 / \mathrm{H} 2 \mathrm{O} \\
\text { - } 0-0.04\end{array}$ & $\begin{array}{l}\text { Conventional TT } \\
\mathrm{TR}=3.0,3.5 \text { and } \\
4.0 \\
\text { Space ratio }=0.3, \\
0.4 \text { and } 0.5 \\
\text { Tape width ratio }= \\
0.5 \text { to } 0.9\end{array}$ & $\begin{array}{c}500 \leq \operatorname{Re} \leq \\
25000\end{array}$ & $\begin{array}{l}\text { - Better heat transfer was obtained in } \\
\text { turbulent flow as compared to laminar } \\
\text { flow using solid nanoparticles at } \\
\text { higher } \varphi \\
\text { - Higher heat transfer was also achieved } \\
\text { by using nanoparticles at lower TR } \\
\text { - Heat transfer was found to be in direct } \\
\text { relation with width of TT and } \varphi \text { in } \\
\text { laminar flow }\end{array}$ & [48] \\
\hline $\begin{array}{l}\text { Numerical } \\
\text { (single phase } \\
\text { approach) }\end{array}$ & $\begin{array}{l}-\mathrm{A} 12 \mathrm{O} 3 / \mathrm{H} 2 \mathrm{O} \\
-0.01-0.04 \\
\text { - } 100\end{array}$ & $\begin{array}{l}\text { Twin TT } \\
\mathrm{TR}=2.5 \text { to } 4.0\end{array}$ & $\begin{array}{c}10000 \leq \operatorname{Re} \leq \\
30000\end{array}$ & $\begin{array}{l}\text { - The value of Nu was reported to } \\
\text { enhance with } \varphi \text { whereas it decreased } \\
\text { with increase in TR } \\
\text { Highest values of } \eta \text { were noted as } 1.6 \\
\text { and } 1.55 \text { respectively at TR }=3.25 \\
\text { and } 2.5 \\
\text { - The improvement in } \eta \text { for counter } \\
\text { swirl flow was found to be more than } \\
\text { co swirl flow }\end{array}$ & [51] \\
\hline Experimental & $\begin{array}{l}-\mathrm{A} 12 \mathrm{O} 3 / \mathrm{H} 2 \mathrm{O} \\
-0.01-0.03 \\
\text { - }<50\end{array}$ & $\begin{array}{l}\text { Conventional TT } \\
\mathrm{TR}=5 \text { to } 20\end{array}$ & $\begin{array}{c}3000 \leq \operatorname{Re} \leq \\
30000\end{array}$ & $\begin{array}{l}\text { - The value of Nu was improved by } \\
31.28 \% \text { and } \mathrm{f} \text { was enhanced by } 1.23 \\
\text { times for TT inserts in nanofluid with } \\
\varphi=0.03 \text { and TR = } 5 \text { as compared to } \\
\text { water }\end{array}$ & [32] \\
\hline $\begin{array}{l}\text { Numerical } \\
\text { (single phase } \\
\text { approach) }\end{array}$ & $\begin{array}{l}\text { - } \mathrm{Al} 2 \mathrm{O} 3 \text { and } \mathrm{SiO} 2- \\
\mathrm{H} 2 \mathrm{O} \\
-0.5-2.0 \\
\text { - } 20-50\end{array}$ & $\begin{array}{l}\text { Helical tape } \\
\text { TR }=1.95 \text { to } 4.89\end{array}$ & $\begin{array}{c}150 \leq \operatorname{Re} \leq \\
2000\end{array}$ & $\begin{array}{l}\text { - } \mathrm{H} 2 \mathrm{O}-\mathrm{A} 12 \mathrm{O} 3 \text { nanofluid was found to } \\
\text { have higher heat transfer enhancement } \\
\& \eta \text { vis-à-vis } \mathrm{H} 2 \mathrm{O}-\mathrm{SiO} 2 \\
\text { - Heat transfer enhancement was noted } \\
\text { to have a direct relation with } \varphi \text { and } \\
\text { inverse relation with the diameter of } \\
\text { nanoparticle } \\
\text { - Nu was found to increase whereas } \mathrm{f} \\
\text { was reported to decrease with } \\
\text { increasing Re }\end{array}$ & [29] \\
\hline $\begin{array}{l}\text { Experimental } \\
\text { Numerical } \\
\text { (single phase } \\
\text { approach) }\end{array}$ & $\begin{array}{ll}\text { - } \mathrm{TiO} 2 / \mathrm{H} 2 \mathrm{O} \\
-0.07,0.14 \text { and } 0.21 \\
\text { - } 15\end{array}$ & $\begin{array}{l}\text { Overlapped dual } \\
\text { TT } \\
\text { TR }=1.5,2.0 \text { and } \\
2.5\end{array}$ & $\begin{array}{c}5400 \leq \operatorname{Re} \leq \\
15200\end{array}$ & $\begin{array}{l}\text { The heat transfer enhancement and } \eta \\
\text { was found to improve by } 9.9-11.2 \% \\
\text { and } 4.5 \% \text { respectively at TR }=1.5, \varphi \\
=0.21 \text { vis-à-vis overlapped dual TT } \\
\text { without nanofluid }\end{array}$ & [43] \\
\hline Experimental & $\begin{array}{l}\text { - } \mathrm{Cu} / \mathrm{H} 2 \mathrm{O} \\
\text { - } 0.1 \text { and } 0.3 \\
\text { - } 30 \text { to } 50\end{array}$ & $\begin{array}{l}\text { TT with variable } \\
\text { (non-uniform) } \\
\text { twist length }\end{array}$ & $\begin{array}{c}7500 \leq \mathrm{Re} \leq \\
15000\end{array}$ & $\begin{array}{l}\text { - Nu and } \mathrm{h} \text { was found to have higher } \\
\text { values in non-uniform TT as } \\
\text { compared to uniform TT } \\
\text { - } \mathrm{h} \text { and } \Delta \mathrm{P} \text { was reported to increase } \\
\text { when short twist length was } \\
\text { introduced at the beginning of TT }\end{array}$ & [37] \\
\hline
\end{tabular}




\begin{tabular}{|c|c|c|c|c|c|}
\hline & & & & $\begin{array}{l}\text { - A combination of nanofluid with wt } \% \\
\text { of } 0.3 \text { and TT with a profile of low to } \\
\text { high was found to improve overall } \\
\text { enhancement ratio by } 87 \%\end{array}$ & \\
\hline $\begin{array}{l}\text { Experimental } \\
\text { Numerical } \\
\text { (single phase } \\
\text { approach) }\end{array}$ & $\begin{array}{ll}- & \mathrm{TiO} 2 / \mathrm{H} 2 \mathrm{O} \\
- & 0.07,0.14 \text { and } 0.21 \\
- & 15\end{array}$ & $\begin{array}{l}\text { Multiple TT with } \\
\text { variable } \\
\text { arrangements } \\
\text { (such as quadruple } \\
\text { counter tapes in } \\
\text { cross direction) } \\
\end{array}$ & $\begin{array}{c}5400 \leq \operatorname{Re} \leq \\
15200\end{array}$ & $\begin{array}{l}\text { - Highest } \eta \text { was reported as } 1.59 \text { while } \\
\text { rate of heat transfer was enhanced by } \\
3.52 \text { times and f was increased to } 11.7 \\
\text { times in the tube inserted CC-QTS } \\
\text { with nanofluid having } \varphi \text { of } 0.21 \text {, as } \\
\text { compared to plain tube with water }\end{array}$ & [44] \\
\hline Experimental & $\begin{array}{l}\text { - } \mathrm{SiO} 2 \text { and } \\
\mathrm{TiO} 2 / \mathrm{H} 2 \mathrm{O} \\
\text { - } 0.01 \text { to } 0.03 \\
\text { - } \mathrm{SiO} 2=30 \\
\text { - } \mathrm{TiO} 2=50\end{array}$ & $\begin{array}{l}\text { Conventional TT } \\
5 \leq \mathrm{TR} \leq 93\end{array}$ & $\begin{array}{c}5000 \leq \mathrm{Re} \leq \\
25000\end{array}$ & $\begin{array}{l}\text { - The value of } \mathrm{h} \text { for } \mathrm{SiO} 2 / \mathrm{H} 2 \mathrm{O} \\
\text { nanofluid with } \varphi=0.03 \text { was found to } \\
\text { be } 27.9 \% \text { higher at } \mathrm{TR}=5 \text { w. } \mathrm{r} \text {. } \mathrm{t} \text {. } \\
\text { water. } \\
\text { - The value of } \mathrm{h} \text { for } \mathrm{TiO} 2 / \mathrm{H} 2 \mathrm{O} \\
\text { nanofluid with } \varphi=0.03 \text { was reported } \\
\text { to be } 11.4 \% \text { higher for tape with } \mathrm{TR}= \\
5 \text { as compared to water. }\end{array}$ & [47] \\
\hline $\begin{array}{l}\text { Experimental } \\
\text { Numerical }\end{array}$ & $\begin{array}{l}\text { - } \mathrm{SiO} 2 / \mathrm{H} 2 \mathrm{O} \\
\text { - } 0.01-0.04\end{array}$ & Conventional TT & $\begin{array}{c}3000 \leq \operatorname{Re} \leq \\
100000\end{array}$ & $\begin{array}{l}\text { An increase in the values of } \mathrm{h} \text { and } \mathrm{f} \\
\text { was found as } 94.1 \% \text { and } 160 \% \\
\text { respectively at } \mathrm{Re}=19046, \mathrm{TR}=5 \\
\text { and } \varphi=0.03 \text { with nanofluid as } \\
\text { compared to water }\end{array}$ & [45] \\
\hline Experimental & $\begin{array}{l}\text { - } \mathrm{TiO} 2 / \mathrm{H} 2 \mathrm{O} \\
\text { - } 0.005 \text { to } 0.03 \\
\text { - } 50\end{array}$ & $\begin{array}{l}\text { Conventional TT } \\
\mathrm{TR}=5 \text { to } 15\end{array}$ & $\begin{array}{c}8000 \leq \mathrm{Re} \leq \\
30000\end{array}$ & $\begin{array}{l}\text { - A vital increase in the value of } \mathrm{h} \text { of } \\
\text { about } 23.2 \% \text { was obtained at } \varphi=0.01 \\
\text { - } \mathrm{h} \text { was found to have an inverse } \\
\text { relation with TR for both nanofluid } \\
\text { and water employing TT } \\
\text { - The values of } \mathrm{h} \text { and } \mathrm{f} \text { were reported to } \\
\text { be } 81.1 \% \text { and } 1.5 \text { times higher using } \\
\text { nanofluid at } \operatorname{Re}=23558, \varphi=1 \% \text { and } \\
\text { TR }=5 \text { w. r. t. water }\end{array}$ & [46] \\
\hline Experimental & $\begin{aligned} &- \text { Propylene glycol } \\
& \text { based } \mathrm{CuO} / \mathrm{H} 2 \mathrm{O} \\
&- 0.025,0.100 \text { and } \\
& 0.500 \\
&-<50\end{aligned}$ & $\begin{array}{l}\text { Conventional TT } \\
\mathrm{TR}=0 \text { to } 15\end{array}$ & $\begin{array}{c}1000 \leq \mathrm{Re} \leq \\
100000\end{array}$ & $\begin{array}{l}\text { - The value of } \mathrm{h} \text { was found to increase } \\
\text { to } 27.95 \% \text { at } \mathrm{CuO}=0.5 \% \text { and } \mathrm{TR}=5 \\
\text { in a plain tube, which was further } \\
\text { enhanced to } 76.06 \% \text { over the base } \\
\text { fluid for same Re } \\
\text { - An increase of } 26.57 \% \text { in } \mathrm{f} \text { was } \\
\text { reported in same conditions }\end{array}$ & [33] \\
\hline Experimental & $\begin{array}{l}\text { - } \mathrm{A} 12 \mathrm{O} 3 / \mathrm{H} 2 \mathrm{O} \\
-0.01 \text { to } 0.03 \\
\text { - }<50\end{array}$ & $\begin{array}{l}\text { Trapezoidal-cut } \\
\text { TT } \\
\text { TR }=5 \text { to } 20\end{array}$ & $\begin{array}{c}3000 \leq \mathrm{Re} \leq \\
30000\end{array}$ & $\begin{array}{l}\text { - It was noticed that } \mathrm{Nu} \text { was enhanced } \\
\text { by } 34.24 \% \text { at } \mathrm{TR}=5 \text { and } 0.03 \% \\
\text { concentration of nanofluid, w. r. t. } \\
\text { water } \\
\text { - It was reported that } \mathrm{f} \text { was increased by } \\
1.29 \text { times at } \mathrm{TR}=5 \text { and } 0.03 \% \\
\text { concentration of nanofluid as } \\
\text { compared to water } \\
\end{array}$ & [31] \\
\hline Experimental & $\begin{array}{l}-\mathrm{A} 12 \mathrm{O} 3 / \mathrm{H} 2 \mathrm{O} \\
-0.01 \text { to } 0.03 \\
-<50\end{array}$ & $\begin{array}{l}\text { Helical tape } \mathrm{TT} \\
\mathrm{TR}=5,10,15 \text { and } \\
20\end{array}$ & $\begin{array}{c}3000 \leq \mathrm{Re} \leq \\
30000\end{array}$ & $\begin{array}{l}\text { - It was reported that Nu was increased } \\
\text { by } 32.91 \% \text { at } \mathrm{TR}=5 \text { and } 0.03 \% \\
\text { concentration of nanofluid, w. r. t. } \\
\text { water } \\
\text { - It was noticed that } \mathrm{f} \text { was enhanced by } \\
1.38 \text { times at } \mathrm{TR}=5 \text { and } 0.03 \% \\
\text { concentration of nanofluid as } \\
\text { compared to water }\end{array}$ & [30] \\
\hline $\begin{array}{l}\text { Numerical } \\
\text { (single phase } \\
\text { approach) }\end{array}$ & $\begin{array}{l}-\mathrm{CuO} / \mathrm{H} 2 \mathrm{O} \\
-0.02 \text { to } 0.04 \\
\text { - } 29\end{array}$ & $\begin{array}{l}\text { Parabolic-cut TT } \\
\text { Cut depth }=0.5 \\
1.0 \text { and } 1.5 \mathrm{~cm} \\
\text { Classical TT } \\
\text { TR }=2.93,3.91 \\
\text { and } 4.89\end{array}$ & $\begin{array}{c}200 \leq \operatorname{Re} \leq \\
2400\end{array}$ & $\begin{array}{l}\text { - It was found that the values of heat } \\
\text { transfer rate and f in both classical TT } \\
\text { and parabolic-cut TT were directly } \\
\text { proportional to TR and inversely } \\
\text { proportional to depth of cut } \\
\text { - Heat transfer rate was reported to } \\
\text { increase with an enhancement in } \varphi \text { of } \\
\text { CuO } \\
\text { - It was demonstrated that Nu of } \\
\text { parabolic-cut TT increased by } 10 \% \\
\text { with a vital increase in f, at cut depth } \\
\text { of } 0.5 \mathrm{~cm} \text { and TR of } 2.93 \text { w. r. t. } \\
\text { classical TT }\end{array}$ & [52] \\
\hline Experimental & $\begin{array}{l}\text { - } \gamma-\mathrm{Al} 2 \mathrm{O} 3 / \mathrm{H} 2 \mathrm{O} \\
-0.005 \text { to } 0.01 \\
\text { - } 10 \text { to } 20\end{array}$ & $\begin{array}{l}\text { Conventional TT } \\
\text { TR }=3.21 \\
\text { Thickness of TT = } \\
0.5,1 \text { and } 2 \mathrm{~mm}\end{array}$ & $\begin{array}{c}150 \leq \mathrm{Re} \leq \\
1600\end{array}$ & $\begin{array}{l}\text { - Nanofluid was found to improve heat } \\
\text { transfer performance with increasing } \\
\text { thickness of TT. It enhanced f as well }\end{array}$ & [41] \\
\hline
\end{tabular}


Hosseinzhad and co-workers [51] studied the turbulence in the flow using twin twisted tapes along with nanofluid in a tubular heat exchanger via numerical pathway. They investigated the co-swirl and counter-swirl flows. They found a direct relation of increase in heat transfer with the nanoparticle concentration and inverse relation with the twist ratio. The performance evaluation criterion was reported to be considerably higher in counter-swirl flow as compared to co-swirl flow. Khoshvaght et al. [37] investigated the influence of twist length on heat transfer enhancement in the presence of nanofluid. They took twisted tape inserts with different lengths such as uniform, low-to-high, high-to-low, low-to-high-tolow and high-to-low-to-high. They reported a vital impact of twist lengths on thermo-hydraulic attributes with 'low to high' twist length having the best characteristics.

In general, it was found that the heat transfer enhancement was better at the outlet of the tube while employing twisted tape inserts with nano fluids on account of the impact of swirl flow; better in the sense that the performance of the device can be improved without enhancing the heat exchanger's size. Moreover, it was noted that a combination of thicker tape inserts with nanofluid has better heat transfer $\eta$ vis-à-vis thinner inserts. Furthermore, the twisted tapes with alternate axes were found to have superior thermal $\eta$ w. r. t. conventional inserts.

\section{DISCUSSIONS}

This paper discusses the impact of TT of diverse configurations, with nano fluids. TT enhances the convective fluid transferis-à-is plain tube on account of the swirl flow generation. The combined effect of TT insert with nanofluid further increases the heat transfer and conveys even better results when thicker tape is employed with nanofluid.

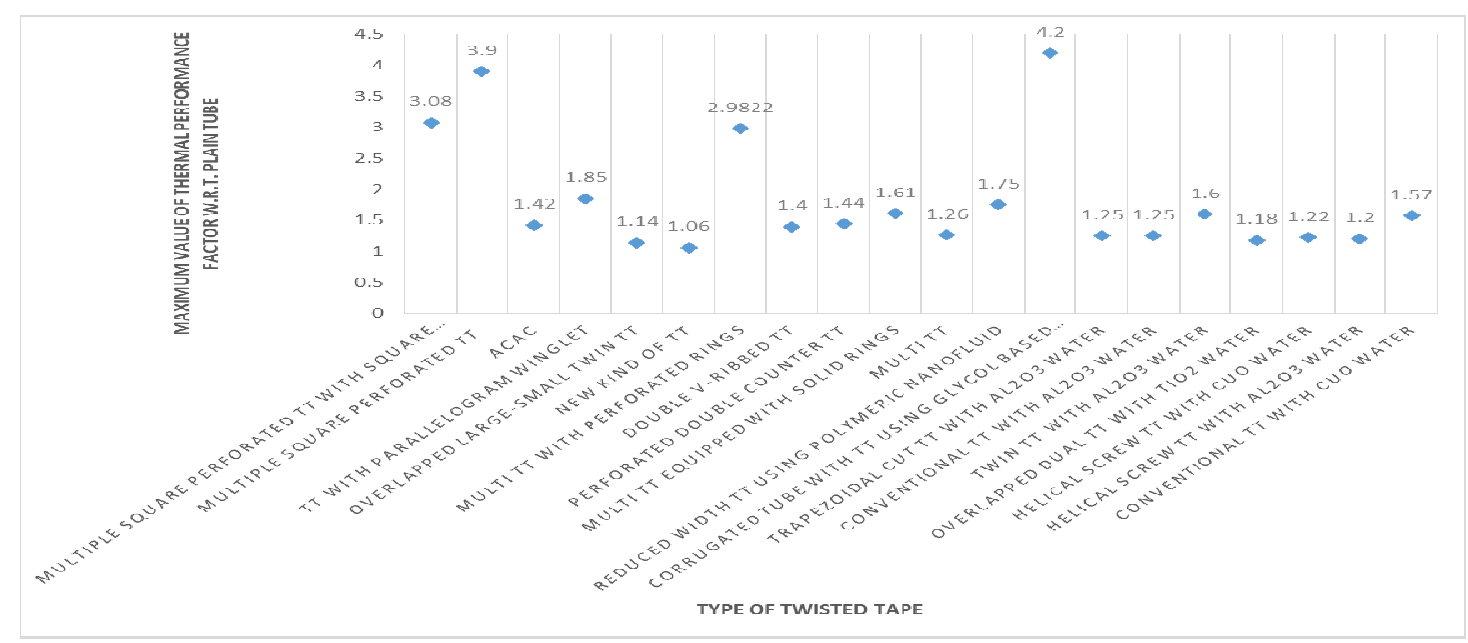

Figure 2: A graph Reflecting the Effects of various TT Configuration and Nanofluid on Thermal Performance Factor $(0.5 \leq$ TR $\leq 7.0)$

A graph is plotted between the types of TT configurations and the maximum values of $\eta$ (w. r. t plain tube) where all the studies took place at TR ranging from 0.5 to 7 , as shown in Fig. 5. It may be noted that the maximum value of $\eta$ among all the studies reviewed is found to be 4.2 in a corrugated tube equipped with TT in the presence of $\mathrm{Al}_{2} \mathrm{O}_{3} / \mathrm{EG}$ nanofluid at $\mathrm{TR}=2$ and $\varphi=0.5 \%$. It is on account of synergetic effect of nanofluid along with a high swirling due to low TR. 


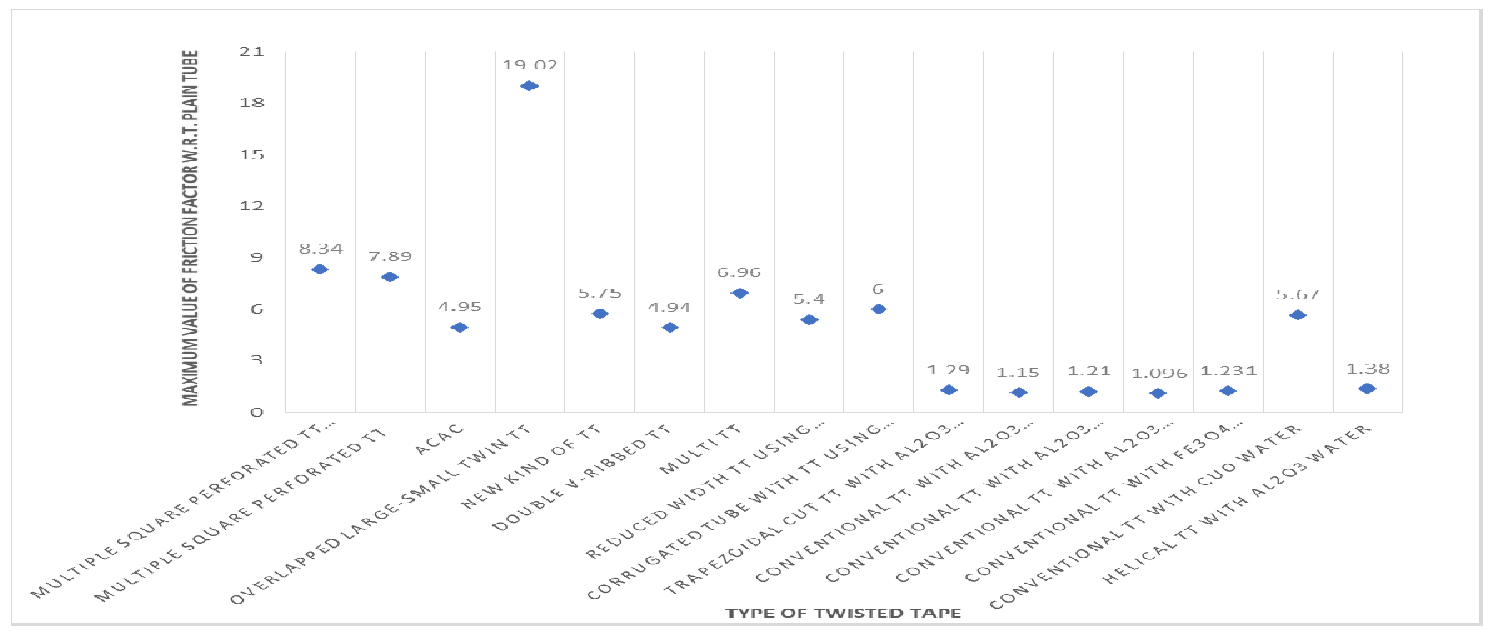

Figure 3: A graph Reflecting the Effects of Various TT Configuration and Nanofluid on Friction Factor $(0.5 \leq T R \leq 7.0)$

Figure 6 is drawn between the types of TT configurations and the maximum values of $\mathrm{f}$ vis-à-vis plain tube for all the reviewed research work. The minimum value of $\mathrm{f}$ is found as 1.15 in conventional tape inserts in the presence of $\mathrm{Al}_{2} \mathrm{O}_{3}$ water $(\varphi=0.03 \%)$ at $\mathrm{TR}=5$ and the flow is in a turbulent region $(\mathrm{Re}=3000)$. It is a plain tube with conventional TT and therefore, the frictional losses are low unlike U-cut, V-cut or grooved shaped inserts and corrugated or spiral tubes.

\section{CONCLUSIONS AND RECOMMENDATIONS}

This article sheds light on different types of twisted tape inserts in double pipe heat exchangers with diverse kinds of nanofluids. The impact of tape inserts on the thermal performance factor, Nusselt Number, friction factor and rate of heat transfer were discussed in a holistic manner. It was observed that, in general, the employment of TT enhances $\mathrm{Nu}, \mathrm{f}, \eta$ and heat transfer rate vis-à-vis plain tube. Specific conclusions with recommendations are mentioned as under:

- Application of twisted tape inserts were demonstrated to be more useful in laminar flows w. r. t. turbulent flows. On the contrary, when solid nanoparticles were employed with a high value of $\varphi$, heat transfer rate was better in turbulent flows than in laminar flows.

- Heat transfer rate was reported to improve with increasing width of TT and volume fraction of nanofluid in laminar flow.

- $\quad \mathrm{Nu}$ and $\mathrm{f}$ were found to improve with decreasing TR and WR and increasing DR in the tube with cut TT inserts. The same was found to be true in the tape inserts with nanofluid where an enhanced heat transfer was recorded at lower TR. In general, $\eta$ was found to have an inverse relation with Re.

- An improvement in the rate of heat transfer was noticed with decreasing diameter of the nanoparticles.

- When TT inserts are employed in the presence of nanofluid, $\mathrm{Nu}$ was found to increase while $\mathrm{f}$ was found to decrease with the rise in Re. 


\section{REFERENCES}

1. Omidi M., Farhadi M., Jafari M. A comprehensive review on double pipe heat exchangers. Appl. Therm. Eng. 110 (2017) 1075-90.

2. Zhang X., Liu Z., Liu W. Numerical studies on heat transfer and flow characteristics for laminar flow in a tube with multiple regularly spaced twisted tapes. Int. J. Therm. Sci. 58 (2012) 157-67.

3. Zhang Z., Yang W., Guan C., Ding Y., Li F., Yan H. Heat transfer and friction characteristics of turbulent flow through plain tube inserted with rotor-assembled strands. Exp. Therm. Fluid Sci. 38 (2012) 33-39.

4. Saha S., Saha S. K. Enhancement of heat transfer of laminar flow of viscous oil through a circular tube having integral helical rib roughness and fitted with helical screw-tapes. Exp. Therm. Fluid Sci. 47 (2013) 81-9.

5. Anvari A. R., Javaherdeh K., Emami-Meibodi M., Rashidi A. M. Numerical and experimental investigation of heat transfer behavior in a round tube with the special conical ring inserts. Energy Convers. Manage. 88 (2014) 214-217.

6. Anvari A., Lotfi R., Rashidi A., Sattari S. Experimental research on heat transfer of water in tubes with conical ring inserts in transient regime. Int. Commun. Heat Mass Transf. 38 (2011) 668-671.

7. Zhang C., Wang D., Ren K., Han Y., Zhu Y., Peng X., et al. A comparative review of self-rotating and stationary twisted tape inserts in heat exchanger. Renew. Sust. Energ. Rev. 53 (2016) 433-449.

8. Zarringhalam M., Karimipour A., Toghraie D. Experimental study of the effect of solid volume fraction and Reynolds number on heat transfer coefficient and pressure drop of CuO-water nanofluid. Exp. Therm. Fluid Sci. 76 (2016) 342-351.

9. $\quad$ Ү X., Yu T., Peng D., Jiang S., Luo J. Twisted strip with oblique teeth to efficiently remove fouling and enhance heat transfer at low flowing velocity. J. Chem. Ind. Eng. (China) 4 (2005).

10. Yu L., Liu D. Study of the Thermal Effectiveness of Laminar Forced Convection of Nanofluids for Liquid Cooling Applications. IEEE Trans. Compo. Packag. Manuf. Technol. 3 (2013) 1693-1704.

11. Yehia M. G., Attia A. A., Abdelatif O. E., Khalil E. E. Heat transfer and friction characteristics of shell and tube heat exchanger with multi inserted swirl vanes. Appl. Therm. Eng. 102 (2016) 1481-91.

12. Yang L., Du K. A comprehensive review on heat transfer characteristics of $\mathrm{TiO}_{2}$ nanofluids. Int. J. Heat Mass Transf. 108 (2017) 11-31.

13. Wongcharee K., Eiamsa-ard S. Friction and heat transfer characteristics of laminar swirl flow through the round tubes inserted with alternate clockwise and counter-clockwise twisted-tapes. Int. Commun. Heat Mass Transf. 38 (2011) $348-352$.

14. Wongcharee K., Eiamsa-ard S. Heat transfer enhancement by twisted tapes with alternate-axes and triangular, rectangular and trapezoidal wings. Chem. Eng. Process.: Process Intensif. 50 (2011) 211-219.

15. Wadekar V. V. Ionic liquids as heat transfer fluids-an assessment using industrial exchanger geometries. Appl. Therm. Eng. 111 (2017) 1581-1587.

16. Vashistha C., Patil A. K., Kumar M. Experimental investigation of heat transfer and pressure drop in a circular tube with multiple inserts. Appl. Therm. Eng. 96 (2016) 117-129.

17. Tuo H., Hrnjak P. Effect of the header pressure drop induced flow maldistribution on the microchannel evaporator performance. Int. J. Refrig. 36 (2013) 2176-2186.

18. Tuo H., Hrnjak P. Flash gas bypass in mobile air conditioning system with R134a. Int. J. Refrig. 35 (2012) 1869-1877. 
19. Tu W., Wang Y., Tang Y. A numerical study on thermal-hydraulic characteristics of turbulent flow through a circular tube fitted with pipe inserts. Appl. Therm. Eng. 101 (2016) 413-421.

20. Thianpong C., Eiamsa-ard P., Wongcharee K., Eiamsa-ard S. Compound heat transfer enhancement of a dimpled tube with a twisted tape swirl generator. Int. Commun. Heat Mass Transf. 36 (2009) 698-704.

21. Thianpong C., Eiamsa-ard P., Promvonge P., Eiamsa-ard S. Effect of perforated twisted-tapes with parallel wings on heat tansfer enhancement in a heat exchanger tube. Energy Procedia. 14 (2012) 1117-1123.

22. Thianpong C., Eiamsa-ard P., Eiamsa-ard S. Heat transfer and thermal performance characteristics of heat exchanger tube fitted with perforated twisted-tapes. Heat Mass Transf. 48 (2012) 881-892.

23. Tamna S., Kaewkohkiat Y., Skullong S., Promvonge P. Heat transfer enhancement in tubular heat exchanger with double Vribbed twisted-tapes. Case Stud. Therm. Eng. 7 (2016) 14-24.

24. Sundar L. S., Otero-Irurueta G., Singh M. K., Sousa A. C. Heat transfer and friction factor of multi-walled carbon nanotubes$\mathrm{Fe}_{3} \mathrm{O}_{4}$ nanocomposite nanofluids flow in a tube with/without longitudinal strip inserts. Int. J. Heat Mass Transf. 100 (2016) 691-703.

25. Song S., Liao Q., Shen W. Laminar heat transfer and friction characteristics of microencapsulated phase change material slurry in a circular tube with twisted tape inserts. Appl. Therm. Eng. 50 (2013) 791-798.

26. Chougule S. S., Sahu S. K. Heat transfer and friction characteristics of Al2O3/water and CNT/water nanofluids in transition flow using helical screw tape inserts - a comparative study. Chem. Eng. Process.: Process Intensif. 88 (2015) 78-88.

27. Singh S., Singh G., Singla A. Experimental studies on heat transfer performance of double pipe heat exchanger with using baffles and nanofluids. Indian J. Sci. Technol. 9 (2016).

28. Sarafraz M., Hormozi F., Nikkhah V. Thermal performance of a counter-current double pipe heat exchanger working with COOH-CNT/water nanofluids. Exp. Therm. Fluid Sci. 78 (2016) 41-49.

29. Sadeghi O., Mohammed H., Bakhtiari-Nejad M., Wahid M. Heat transfer and nanofluid flow characteristics through a circular tube fitted with helical tape inserts. Int. Commun. Heat Mass Transf. 71 (2016) 234-244.

30. Prasad P. D., Gupta A., Sreeramulu M., Sundar L. S., Singh M., Sousa A. C. Experimental study of heat transfer and friction factor of Al2O3 nanofluid in U-tube heat exchanger with helical tape inserts. Exp. Therm. Fluid Sci. 62 (2015) 141-150.

31. Prasad PD, Gupta A, Deepak K. Investigation of trapezoidal-cut twisted tape insert in a double pipe U-tube heat exchanger using Al2O3/water nanofluid. Procedia Mater. Sci. 10 (2015) 50-63.

32. Prasad P. D., Gupta A. Experimental investigation on enhancement of heat transfer using Al2O3/water nanofluid in a u-tube with twisted tape inserts. Int. Commun. Heat Mass Transf. 75 (2016) 154-161.

33. Naik M., Janardana G. R., Sundar L. S. Experimental investigation of heat transfer and friction factor with water-propylene glycol based $\mathrm{CuO}$ nanofluid in a tube with twisted tape inserts. Int. Commun. Heat Mass Transf. 46 (2013) 13-21.

34. Mohammadiun H., Mohammadiun M., Hazbehian M., Maddah H. Experimental study of ethylene glycol-based Al2O3 nanofluid turbulent heat transfer enhancement in the corrugated tube with twisted tapes. Heat Mass Transf. 52 (2016) 141 151.

35. Mashayekhi R., Khodabandeh E., Bahiraei M., Bahrami L., Toghraie D., Akbari O. A. Application of a novel conical strip insert to improve the efficacy of water-Ag nanofluid for utilization in thermal systems: a two-phase simulation. Energy Convers Manage. 151 (2017) 573-586. 
36. Maddah H., Alizadeh M., Ghasemi N., Wan Alwi S. R. Experimental study of Al2O3/water nanofluid turbulent heat transfer enhancement in the horizontal double pipes fitted with modified twisted tapes. Int. J. Heat Mass Transf. 78 (2014) 1042-1054.

37. Khoshvaght-Aliabadi M., Eskandari M. Influence of twist length variations on thermal-hydraulic specifications of twistedtape inserts in presence of Cu-water nanofluid. Exp. Therm. Fluid Sci. 61 (2015) 230-240.

38. Hussein A. M., Bakar R. A., Kadirgama K., Sharma K. V. Heat transfer enhancement with elliptical tube under turbulent flow TiO2-water nanofluid. Therm. Sci. 20 (2016) 89-97.

39. Hazbehian M., Maddah H., Mohammadiun H., Alizadeh M. Experimental investigation of heat transfer augmentation inside double pipe heat exchanger equipped with reduced width twisted tapes inserts using polymeric nanofluid. Heat Mass Transf. 52 (2016) 2515-2529.

40. Goodarzi M., Kherbeet A. S., Afrand M., Sadeghinezhad E., Mehrali M., Zahedi P., et al. Investigation of heat transfer performance and friction factor of a counter-flow double-pipe heat exchanger using nitrogen-doped, graphene-based nanofluids. Int. Commun. Heat Mass Transf. 76 (2016) 16-23.

41. Esmaeilzadeh E., Almohammadi H., Nokhosteen A., Motezaker A., Omrani A. N. Study on heat transfer and friction factor characteristics of $\gamma$-Al2O3/water through circular tube with twisted tape inserts with different thicknesses. Int. J. Therm. Sci. $82(2014) 72-83$.

42. El-Maghlany W. M., Hanafy A. A., Hassan A., El-Magid M. A. Experimental study of Cu-water nanofluid heat transfer and pressure drop in a horizontal double-tube heat exchanger. Exp. Therm. Fluid Sci. 78 (2016) 100-111.

43. Eiamsa-Ard S., Kiatkittipong K., Jedsadaratanachai W. Heat transfer enhancement of TiO2/water nanofluid in a heat exchanger tube equipped with overlapped dual twisted-tapes. Int. J. Eng. Sci. Technol. 18 (2015) 336-350.

44. Eiamsa-ard S., Kiatkittipong K. Heat transfer enhancement by multiple twisted tape inserts and TiO2/water nanofluid. Appl. Therm. Eng. 70 (2014) 896-924.

45. Azmi W. H., Sharma K. V., Sarma P. K., Mamat R., Anuar S., Syam Sundar L. Numerical validation of experimental heat transfer coefficient with SiO2 nanofluid flowing in a tube with twisted tape inserts. Appl. Therm. Eng. 73 (2014) 296-306.

46. Azmi W. H., Sharma K. V., Sarma P. K., Mamat R., Anuar S. Comparison of convective heat transfer coefficient and friction factor of TiO2 nanofluid flow in a tube with twisted tape inserts. Int. J. Therm. Sci. 81 (2014) 84-93.

47. Azmi W., Sharma K., Mamat R., Anuar S. Turbulent forced convection heat transfer of nanofluids with twisted tape insert in a plain tube. Energy Procedia. 52 (2014) 296-307.

48. Rambabu, V., RAMARAO, J., \& BABU, S. R. (2017). Enhancement of Heat transfer in Shell and Tube Heat Exchanger by Using Nano Fluid. International Journal of Mechanical and Production Engineering Research and Development, 7 (5), 191 198.

49. Akbari O. A., Afrouzi H. H., Marzban A., Toghraie D., Malekzade H., Arabpour A. Investigation of volume fraction of nanoparticles effect and aspect ratio of the twisted tape in the tube. J. Therm. Anal. Calorim. 129 (2017) 1911-1922.

50. Sharma K., Sundar L. S., Sarma P. Estimation of heat transfer coefficient and friction factor in the transition flow with low volume concentration of $\mathrm{Al}_{2} \mathrm{O}_{3}$ nanofluid flowing in a circular tube and with twisted tape insert. Int. Commun. Heat Mass Transf. 36 (2009) 503-507.

51. Sundar L. S., Kumar N. R., Naik M., Sharma K. Effect of full length twisted tape inserts on heat transfer and friction factor enhancement with Fe3O4 magnetic nanofluid inside a plain tube: an experimental study. Int. J. Heat Mass Transf. 55 (2012) $2761-2768$. 
52. Hosseinnezhad R., Akbari O. A., Afrouzi H. H., Biglarian M., Koveiti A., Toghraie D. Numerical study of turbulent nanofluid heat transfer in a tubular heat exchanger with twin twisted-tape inserts. J. Therm. Anal. Calorim. 132 (2018) 741-759.

53. Salman S. D., Kadhum A. A. H., Takriff M. S., Mohamad A. B. Heat transfer enhancement of laminar nanofluids flow in a circular tube fitted with parabolic-cut twisted tape inserts. The Sci World J. 2014 (doi.org/10.1155/2014/543231) 